\title{
Gondolatok a 2019. évi új európai dyslipidaemia és krónikus koronáriaszindróma ajánlások kapcsán
}

\author{
Márk László', Bajnok László², Reiber István ${ }^{3}$ \\ 1Békés Megyei Központi Kórház Pándy Kálmán Tagkórház, Kardiológia Osztály, Gyula \\ ${ }^{2}$ Pécsi Tudományegyetem, Klinikai Központ, I. sz. Belgyógyászati Klinika, Endokrinológiai és \\ Anyagcsere Tanszék, Pécs \\ ${ }^{3}$ Fejér Megyei Szt. György Egyetemi Oktató Kórház, Székesfehérvár \\ Levelezési cím: \\ Dr. Márk László, Békés Megyei Központi Kórház, Pándy Kálmán Tagkórház, Kardiológia Osztály \\ 5700 Gyula, Semmelweis u. 1. E-mail: dr.mark.laszlo@gmail.com
}

\begin{abstract}
Az Európai Kardiológus Társaság (ESC) 2019-ben új irányelveket adott ki a dyslipidaemia és a krónikus koronáriaszindróma (CCS) kezeléséröl $(1,2)$.

A kardiológia legnagyobb kihívása az iszkémiás szívbetegség (ISZB) megfelelő kezelése és az ISZB okozta halálozás csökkentése. Ezért érthetö, hogy stabil ISZB, vagy új nevén a CCS új európai ajánlása kapcsán a Cardiologia Hungarica két legutóbbi számában reflexió jelent meg $(3,4)$. Ezekben az irányelv elöremutató aspektusainak dicsérete mellett (pl. a konzervatív, gyógyszeres stratégiában a nitrátok visszaszorulása, a trimetazidin és az ivabradin elöretörése), megfogalmazódnak kételyek is az ajánlott diagnosztikai utak megvalósíthatóságáról és a javasolt terápia egyes elemeinek evidenciahátteréről. Vitatott kérdések, hogy a diagnózisban mennyire napi szinten használható a koronária-CT, vagy hogy a CCS-ben hol van a koronarográfia és a perkután intervenció $(\mathrm{PCl})$ helye. $\mathrm{Az}$ akut koronáriaszindróma (ACS) invazív megoldása a kardiológusok legvonzóbb és leglátványosabb tevékenysége. Ez teljességgel érthető, hiszen egy elzáródott ér megnyitása megmentheti a beteg életét és meghosszabbíthatja életkilátásait. Az akut éresemény invazív megoldásának hosszú távú kedvező eredményei alapján világszerte több mint félmillió $\mathrm{PCl}$ történik évente CCS-ben az anginás panaszok csökkentése céljából. Azonban a randomizált klinikai vizsgálatok
\end{abstract}

nem igazoltak egyértelmü hasznot a különböző kimenetelek tekintetében, csak csökkent ejekciós frakciójú szívelégtelenség esetén.

\section{Optimális konzervatív kezelés vs. invazív stratégia CCS-ben klinikai vizsgálatok alapján}

A 2007-ben közölt Clinical Outcomes Utilizing Revascularization and Aggressive Drug Evaluation (COURAGE) vizsgálatban 2287, angiográfiával kimutatott szignifikáns koronáriaszükületes, stabil angina pectorisos beteget két csoportra randomizáltak. A betegek fele $\mathrm{PCl}-\mathrm{n}$ esett át, majd optimális gyógyszeres terápiában részesült, a másik fele $\mathrm{PCI}$ nélkül kapott optimális konzervatív kezelést. A 4,6 éves átlagos követési idő alatt a primer végpontban (bármilyen eredetủ halál vagy miokardiális infarktus) nem volt szignifikáns különbség a két csoport között (5). A Nagy-Britanniában végzett Objective Randomised Blinded Investigation with optimal medical Therapy of Angioplasty in stable angina (ORBITA) vizsgálatban 230 olyan beteget randomizáltak $\mathrm{PCl}$-re és maszkírozott beavatkozásra (amikor PCl-t nem végeztek el egy azt imitáló beavatkozás során) és minden beteg kapta az evidenciákon alapuló gyógyszeres terápiát. A primer végpont a terhelés ideje volt, mely PCl-csoportban nem szig-

A kézirat 2020. 04. 08-án érkezett a szerkesztőségbe, 2020. 05. 11-én került elfogadásra. 
nifikánsan, 16,6 másodperccel bizonyult hosszabbnak, és nem volt szignifikáns különbség az $1 \mathrm{~mm}$-es ST-depresszióig eltelt időben, valamint a kérdőívekkel felmért anginás panaszok gyakoriságában (6). 2019ben mutatták be az ISCHEMIA (International Study of Comparative Health Effectiveness with Medical and Invasive Approaches) eredményeit, amelyben stabil koronáriabetegségben szenvedőkön vizsgálták az optimális gyógyszeres kezelés és az emellett alkalmazott $\mathrm{PCl}$ kardiovaszkuláris eseményekre kifejtett hatását. Ebben 5179 közepes vagy súlyos, egyébként stabil koronáriaszűkületes beteget randomizáltak invazív stratégiára (revaszkularizáció + optimális gyógyszeres kezelés) és konzervatív stratégiára (csak optimális gyógyszeres kezelés). Sem a primer végpontban (kardiovaszkuláris halál, instabil angina miatti hospitalizáció, szívelégtelenség, újraélesztés szívmegállás miatt), sem major szekunder végpontban (kardiovaszkuláris halál vagy szívinfarktus) nem volt szignifikáns különbség a két csoport között $(p=0,34$, illetve $p=0,21)$ (7).

\section{A lipidszintek és célértékek a beteggondozásban}

A stabil ISZB kivizsgálásával kapcsolatban az új CCS-irányelvben írottak betarthatóságáról aggályokat vet fel Tomcsányi és munkatársai közlése (3), a jelen magyar valóságban a lehetőségeink nem teszik lehetővé a koronária-CT ajánlások szerinti gyakoriságban történő alkalmazását. Ugyanakkor a dyslipidaemia kezelésében még bőséges tartalékok vannak. Kétségtelen, hogy az új irányelvek által előírt alacsonyabb LDL-koleszterin (LDL-C) szintek eléréséhez gyakrabban kellene a PCSK9-gátlók alkalmazását elkezdenünk (8), ami a jelenlegi hazai szabályozásban még korlátozva van, de vitathatatlan, hogy a statin-monoterápia vagy a statin és ezetimib adásából álló kombináció nyújtotta lehetőségek sincsenek a csúcsra járatva. Ennek okait keresve javasolt a gyulai kardiológiai munkacsoport egy megtervezett gondozási stratégiát, amelyben a kontrollra hívás fix időponttal történne és ekkor a beteg mindig hozna magával friss lipideredményt, amire a beutalót a megelőző vizsgálat során adná az orvos (9). Az ezetimib felírásának elmaradására érvként lehetne felhozni, hogy jelenleg az emelt támogatás szakorvosi javaslathoz és megfelelő diagnózis alapján eü. ponthoz kötött (ennek megváltoztatását a Magyar Kardiológusok Társasága és a Magyar Atherosclerosis Társaság kérte az illetékes hatóságtól). Három hónappal az éresemény után már javaslatot lehetne adni a szedésre, csak el kellene végezni a lipidellenőrzéseket és mérlegelni kellene a kezelés elindítását (ezt gátolhatja, hogy a kardiológiai ellenőrzéskor a betegnek gyakran nincs friss laboreredménye). Egy bizonyíték arra, hogy nem „gondolunk” kellő gyakorisággal az ezetimib adására, hogy a Nemzeti Szívinfarktus Regiszter adatai szerint a recidív ACS miatt a $\mathrm{PCl}-n$ átesett betegek egytizede kap a kórházi távozáskor ezetimib javaslatot, pedig az ő esetükben a korábbi esemény alapján nem lenne annak szabályozási akadálya (9).

\section{A lipidcsőkkentéssel elérhető kardiovaszkuláris nyereség}

Nyilvánvaló, hogy a megfelelö lipidcsökkentéssel a legnagyobb nyereség a súlyosabb betegek kezelése során várható, ezért is történt az új ajánlásban az igen nagy kockázatú kategóriában a célérték $1,4 \mathrm{mmol} / \mathrm{l}-$ re csökkentése. A legnagyobb guideline-t formáló ereje ebben a leszállításban a koleszterinfelszívódást gátló ezetimibbel, valamint a PCSK9-inhibitorokkal történt nagy klinikai vizsgálatoknak volt.

Az egész dyslipidaemia-ajánlást az élethosszig tartó kockázatcsökkentés (lifetime risk) igénye hatja át. Milyen érvek szólnak a korán elkezdett, hosszú távon folytatott lipidcsökkentés mellett? Az elérhető haszon megbecslésére többféle megközelítés lehetséges.

\section{A kumulatív LDL-C-küszo̊b elérésének to̊bb évvel to̊rténő eltolása}

Az ateroszklerózis folyamata kialakulásának és a korai kezelés elkezdésének fontosságát a kumulatív LDL-terhelés koncepciója igazolja. Ezt az Európai Atherosclerosis Társaság (EAS) a familiáris hypercholesterinaemiával $(\mathrm{FH})$ kapcsolatban közölte (10) és a lényege, hogy minden életévre feltételez egy átlagos LDL-C-szintet, és ezeket évente összeadja. A koncepció szerint az ISZB kialakulásához $160 \mathrm{mmol} / \mathrm{l}$ összes LDL-C-terhelés szükséges, azaz az egyes életévekre jellemző LDL-C-szinteket összeadva a 160-at elérve alakul ki a koszorúerek szükülete. Ha feltételezzük, hogy pl. egy homozigóta FH-ban az LDL-C 12 mmol/l, ezen értékkel számolva évente, már a tízes életévek elején elérhető a $160 \mathrm{mmol} / \mathrm{l}$ kumulatív küszöb (ezek a betegek fiatalon szoktak meghalni érszükületes események miatt). Heterozigóta FH-ban (amelynek gyakorisága újabb adatok szerint 1:250) $5 \mathrm{mmol} / \mathrm{l}$ LDL-C-vel számolva a 30 -as évek elején éri el a beteg a kritikus értéket, de korai kezeléssel, minél fiatalabb életkorban elkezdett lipidcsökkentéssel a küszöbérték elérése sokat késleltethető. Emiatt forszírozzák az európai orvosi társaságok az FH időben történő felismerését és kezelését. A kumulatív LDL-elvet nem csupán $\mathrm{FH}$-eseteire lehet alkalmazni. Braunwald víziója szerint a 30 éves korban elkezdett koleszterincsökkentéssel akár évtizedeket is lehet nyerni a kardiovaszkuláris halálozás viszszaszorításával $(11,12)$. 


\section{Kardiovaszkuláris betegségtől mentes életévekben mért nyereség primer prevencióban}

$A z$, hogy egy egyén mit nyerhet hosszú távon a prevenciós terápiától, a rizikóstátuszától és a megelöző terápia hosszától függ. Jaspers és munkatársai a Multi-Ethnic Study of Atherosclerosis vizsgálat 6715 primer prevenciós betegcsoportjának adatai alapján kifejlesztettek egy interneten is hozzáférhető (www.U-Prevent.com) kalkulátort, amely a koleszterin- és vérnyomáscsökkentő, antitrombotikus kezelés, valamint a dohányzáselhagyás élethosszi nyereségét állapítja meg. (A nyerhető adatok validálását három nagy, sokéves követéses vizsgálat közel 37 ezer betegén végezték.) Az 1. ábra azt mutatja meg, hogy milyen nyereség várható $40 \mathrm{mg}$ atorvastatin szedésétöl és a vérnyomás $130 \mathrm{Hgmm}$ alatt tartásától nem diabéteszes, korábban dohányzó beteg esetén. A 70 és a 45 éves, induláskor hasonló rizikófaktorok mellett a megelőző kezeléssel a 10 éves abszolút kockázat- csökkenés jelentősebb az idősebb betegben (15,4\% vs. $1,4 \%$ ), ugyanakkor valamivel mérsékeltebb kardiovaszkuláris betegségtől mentes életév-többletre számíthat $(3,4$ vs. 4,5$)(13,14)$.

\section{Az LDL-C-célérték elérésével megelőzo̊tt infarktusok száma szekunder prevencióban}

A 170 ezer statint szedő beteg adatait felölelő Cholesterol Treatment Trialists' Collaboration (CTTC) metaanalízis (15) eredményei alapján megállapítható, hogy a különböző LDL-C-értékekhez mekkora kockázat tartozik, és az, hogy az mennyit javulna, ha az LDL-C egyik értékről a másikra csökkenne. Eszerint, ha 2,5röl 2,0-ra vagy $1,8 \mathrm{mmol} / \mathrm{l}-\mathrm{re}(0,5-0,7 \mathrm{mmol} / \mathrm{l}-\mathrm{rel})$ csökkentenénk az LDL-C-t, 10 év alatt 100 beteg kezelésével 3 infarktus, stroke vagy haláleset lenne elkerülhető. Ha 4,0 mmol// LDL-C-szintröl érjük el az 1,8-at, akkor 100 beteg kezelésével öt év alatt 5 , tíz év alatt 10 kardiovaszkuláris eseményt előzhetnénk meg (16).

„A" beteg, kor: 70 év; LDL-C: 4,0 mmol/l; RRs: 160 Hgmm
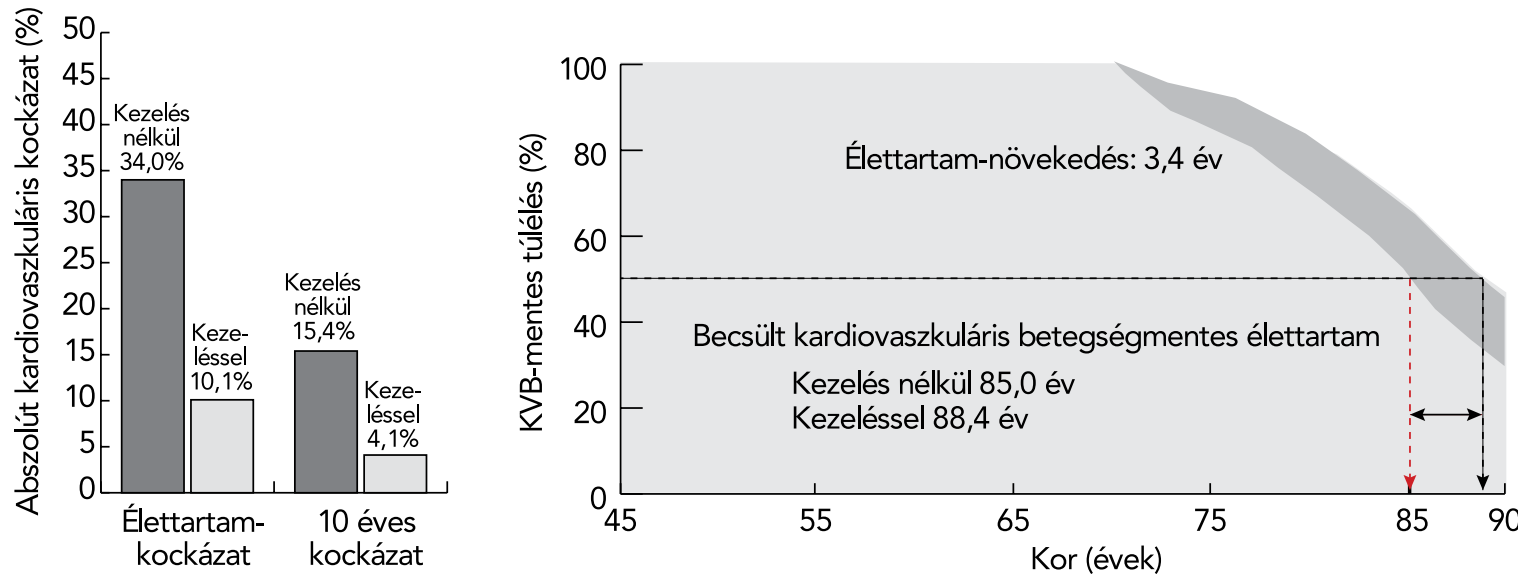

„B" beteg, kor: 45 év; LDL-C: 4,0 mmol/l; RRs: 160 Hgmm
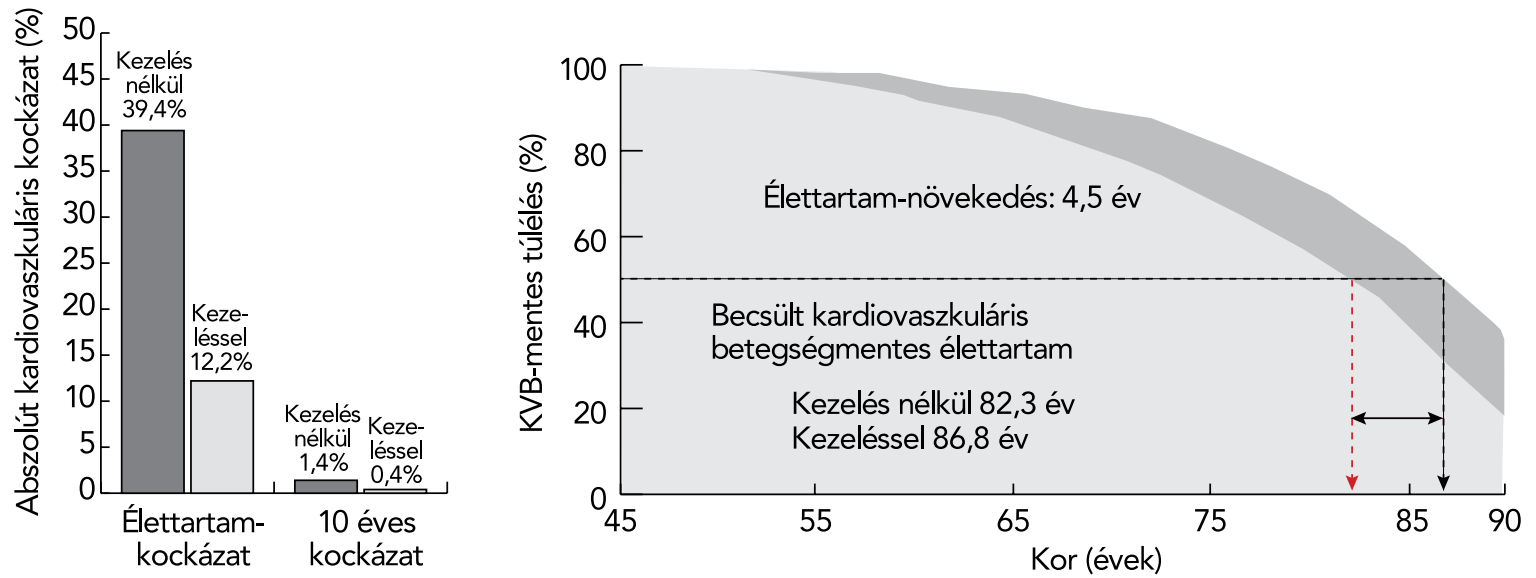

1. ÁBRA. 40 mg atorvastatin szedésével és a vérnyomás 130 Hgmm-en tartásával nem diabéteszes, korábban dohányzó beteg esetén várható kardiovaszkuláris betegségtől mentes élettartam-nyereség (13, 14 nyomán) 


\section{Következtetések}

Sokkal jobb és célravezetöbb lenne az ateroszklerotikus alapú érbetegségek kialakulásának megelőzése, mint a későbbi stádiumban történő intervenció. A prevencióban nagy szerepe lenne az irányelvek szerint elvégzett - életmód-tanácsadás és vérnyomáskontroll mellett - a lipidcsökkentésnek (amellyel sokszorosan igazoltan lehet nemcsak az ateroszklerotikus plakk regresszióját, hanem a kardiovaszkuláris események csökkenését is elérni). Ugyanakkor a dyslipidaemia kezelése az éresemény utáni esetekben, kiemelkedő fontosságú.

$A z$ irányelvek szerinti prevenciós kezelés elmaradása nem hazai sajátosság. A már említett ISCHEMIA-tanulmányban a kiindulási $20 \%$-ról klinikai vizsgálati körülmények között is csak $40 \%$-ra emelkedett azon betegek aránya, akik elérték az 1,8 mmol/l LDL-C-t, $140 \mathrm{Hgmm}$ alatti volt a szisztolés vérnyomásuk, vérlemezkegátló kezelést kaptak és nem dohányoztak (7). Általában elmondható, hogy a prevenciós lehetőségek közül a lipidcsökkentés a mostohagyerek, a célértékek elérése, a (korábban számottevőbb, mára már lassúbb) javulás ellenére, itt a legalacsonyabb. Ma már kardiológusok között viszonylag elfogadott és általános a statin adása ACS utáni beteg esetében. Kérdés, hogy mikor jutunk el oda, hogy szégyen lesz nem törekedni a célértékek elérésére, legalább maximálisan tolerált statint és ezetimibet adva?

\section{Nyilatkozat \\ A szerzök kijelentik, hogy az összefoglaló közle- mény megírásával kapcsolatban nem áll fenn velük szemben pénzügyi vagy egyéb lényeges összeütkö- zés, összeférhetetlenségi ok, amely befolyásolhatja a közleményben bemutatott eredményeket, az abból levont következtetéseket vagy azok értelmezését.}

\section{Irodalom}

1. Knuut J, Wijns W, Saraste A, Capodanno D, Barbato E, et al. 2019 ESC Guidelines for the diagnosis and management of chronic coronary syndromes. The Task Force for the diagnosis and management of chronic coronary syndromes of the European Society of Cardiology (ESC). Eur Heart J 2020; 41: 407-477.

https://doi.org/10.1093/eurheart/ehz 425

2. Mach F, Baigent C, Catapano AL, et al; ESC Scientific Document Group. 2019 ESC/EAS Guidelines for the management of dyslipidaemias: lipid modification to reduce cardiovascular risk. Eur Heart J 2020; 41: 111-188. https://doi.org/10.1093/eurheartj/ehz455
3. Tomcsányi J, Jánosi A, Turi-Kováts N. Gondolatok a krónikus koronária szindróma ESC ajánlásának hazai alkalmazásáról. Cardiol Hung 2019; 49: 424-426.

https://doi.org/10.26430/CHUNGARICA.2019.49.6.424

4. Ahres A, Andrássy P. Gondolatok az Európai Kardiológusok Társaságának 2019. évi krónikus koronáriaszindróma ajánlásáról. Cardiol Hung 2020; 50: 35-37.

https://doi.org/10.26430/CHUNGARICA.2020.50.1.35

5. Boden WE, O'Rourke RA, Teo KK, et al; COURAGE Trial Research Group. Optimal medical therapy with or without PCI for stable coronary disease. N Engl J Med 2007; 356: 1503-1516.

https://doi.org/10.1056/NEJMoa070829

6. Al-Lamee R, Thompson D, Dehbi HM, et al.; ORBITA investigators. Percutaneous coronary intervention in stable angina (ORBITA): a double-blind, randomised controlled trial. Lancet 2018; 391: $31-$ 40. https://doi.org/10.1016/S0140-6736(17)32714-9

7. Maron DJ, Hochman JS, Reynolds HR, et al. for the ISCHEMIA Research Group. Initial Invasive or Conservative Strategy for Stable Coronary Disease N Engl J Med 2020; 382: 1395-1407.

https://doi.org/10.1056/NEJMoa1915922

8. Bajnok L. Az Európai Ateroszklerózis Társaság (EAS) és az Európai Kardiológiai Társaság (ESC) dyslipidaemia ajánlása. Fókuszban az igen nagy kockázatúak. Metabolizmus 2019; 17: 262-265.

9. Márk L, Dani Gy, Ozsváth L, Szabó-Györke I, Katona A, Jambrik Z. Akut koronáriaszindróma miatt intervención átesett betegeink lipidcsökkentő kezelése és ajánlás a beavatkozás utáni ellenőrzésekre. Card Hung 2020; 50: 29-34.

https://doi.org/10.26430/CHUNGARICA.2020.50.1.29

10. Nordestgaard BG, Chapman MJ, Humphries SE, et al; European Atherosclerosis Society Consensus Panel. Familial hypercholesterolaemia is underdiagnosed and undertreated in the general population: guidance for clinicians to prevent coronary heart disease: consensus statement of the European Atherosclerosis Society. Eur Heart J 2013; 34: 3478-3490.

https://doi.org/10.1093/eurheartj/eht273

11. Braunwald E. CAD 10 years from now. My predictions and how to get yourself ready. European Society of Cardiology Congress 2018. Munich, Germany; Presented August 27, 2018.

12. Márk L. Az atherosclerosis nemcsak megelőzhető, hanem gyógyítható is. LAM 2019; 29: 121-127. DOI: 10.33616/lam.29.0000 13. Lüscher TF. Towards individualized lifetime risk: combining classical and non-classical factors. Eur Heart J 2020; 41: 1143-1147 https://doi.org/10.1093/eurheartj/ehaa155

14. Jaspers NEM, Blaha MJ, Matsushita K, et al. Prediction of individualized lifetime benefit from cholesterol lowering, blood pressure lowering, antithrombotic therapy, and smoking cessation in apparently healthy people. Eur Heart J 2020; 41: 1190-1199. https://doi.org/10.1093/eurheartj/ehz239

15. Baigent C, Blackwell L, Emberson J, et al. Cholesterol Treatment Trialists' CTT Collaboration. Efficacy and safety of more intensive lowering of LDL cholesterol: a meta-analysis of data from 170000 participants in 26 randomised trials. Lancet 2010; 376: 1670-1681. https://doi.org/10.1016/S0140-6736(10)61350-5

16. Márk L. Hány cardiovascularis eseményt előzhetünk meg a prevenciós elvek szerint vezetett lipidcsökkentő kezeléssel? LAM 2019; 29: 289-294. https://doi.org/10.33616/lam.29.029 